\title{
TEACHING SPEAKING BY USING QUARTET CARD GAME AT SPMN 275, EAST JAKARTA
}

\author{
Doni Anggoro Ari Santoso
}

\author{
Program Studi Pendidikan Bahasa Inggris \\ Fakultas Bahasa dan Seni, Universitas Indraprasta PGRI \\ don.okba@gmail.com
}

\begin{abstract}
Abstrak
Permainan adalah salah satu teknik yang digunakan guru untuk membantu siswa dalam menguasai keterampilan berbicara bahasa Inggris. Permainan sangat menarik ketika digunakan dalam mempelajari bahasa Inggris di kelas. Permainan sangat menyenangkan dan diharapkan dapat membantu siswa yang pemalu untuk dapat aktif dalam menunjukkan kemampuannya dalam berkomunikasi dalam bahasa Inggris. Tujuan dari penelitian ini untuk menjelaskan penggunaan permainan kartu Quartet dalam mengajar keterampilan berbicara bahasa Inggris di SMP 275, Jakarta Timur. Kartu Quartet digunakan untuk membantu siswa dalam belajar keterampilan berbicara bahasa Inggris, yang di dalamnya terdapat banyak gambar dan kata yang dapat membantu siswa dalam belajar. Pengumpulan data penelitian ini melalui observasi, wawancara, diskusi, buku dan juga dokumentasi. Melalui data tersebut, peneliti menemukan peranan kartu Quartet dan juga keefektifan permainan dalam mengajar keterampilan berbicara bahasa Inggris.
\end{abstract}

Kata Kunci: mengajar, keterampilan berbicara, kartu Quartet, permainan.

\begin{abstract}
Game is one of the techniques that is used by teachers to help the students in practicing speaking in order to make them able to master it. Games are highly motivating when it is used to practice language skills in English in the classroom. Games also provide fun and relax when it is used in the classroom, it is expected for shy and slow learners can be active participants to show their ability and find their confidence in communicating in the foreign language. The research aims to describe the use of Quartet Card Game in teaching speaking at SMPN 275, East Jakarta. The Quartet Card Game is used to help the students in practicing language skills, especially speaking. Quartet Card Game has so many varieties pictures and words that can be used by the students in learning speaking skill. The data are collected through observation, interview, discussion, books and also documentation. By the data, the research finds the role of Quartet Card Game in teaching speaking. The research findings also prove the effectiveness of the game in teaching
\end{abstract}

Keywords: Teaching, speaking, quartet card, game.

\section{INTRODUCTION}

All students hope that they are able to communicate in English by mastering the whole skills. However, it is not easy to do so; there must be one important skill that covers the whole skills. In some contexts, speaking ability seems to be the most important of the four skills; furthermore, test takers' performance in each of the four skill areas is usually very highly related, so this strategy may not be an entirely unreasonable (Powers, 2010). Based on the statement, speaking is the most 
important skill that should be mastered by the students in order to communicate in English fluently.

In this case the students must study hard to master it and the teachers should create a good atmosphere in class, but it is contrary to the real situation in class. Speaking activities do not work in class because many factors prevent the students from speaking English with their friends. They are afraid of making mistakes, of being laughed at by his or her friends, and of having lack of confidence in their own ability. The worst problem is the classes are too big for speaking activities and they have too little time to speak.

Considering problems relating to speaking activities in class and helping students to improve their speaking skill is part of the teachers' job. He or she is expected to have right teaching techniques to provide students with appropriate teaching materials and to create a positive classroom environment. So, the students will have opportunity to use English among themselves. The teaching - learning process should not only happen between teacher and students but also between students and students.

Speaking is an activity used by someone to communicate with others. It takes place everywhere and has become part of our daily activities. When someone speaks, he or she interacts and uses the language to express his or her ideas, feeling, and thought. He or she also shares information to other through communication. Powers (2010) said, "Speaking is to express the needs request, information, services, etc." In order to express his or her needs, ideas, feeling, and thought in real communication, one must be able to ask as well as answer questions. Question and answer are major elements in natural conversation sessions.
In the classroom the teachers must create the situation which can encourage real communication; many activities can be designed to make these major elements lively. Game is one of the techniques that can be applied in teaching speaking because game is one of potential activity that gives students feeling of freedom to express themselves. Game is also potentially useful to encourage students to interact with each other orally.

Teaching speaking at SMPN 275 is really needed. It happens so because speaking skill is the main purpose of learning English. However, many students still reluctant and face so many difficulties in learning and practicing speaking skill. Some students said that the teacher always teach monotonously, so that they can easily feel bored and difficult to communicate in English. Some others also say that they are afraid of making mistakes. In this problem, the teachers should think of the solving on this matter.

Quartet card game is the right technique to motivate students to speak freely because games are combination between language practice and fun. They can express their ideas freely because they do the activities with their friends. This game is also easy to administer and flexible in terms of subject matter and design. In this research, the researchers focus on the use of quartet card game. The reason for using quartet card game is to give more opportunities for the students to take turns in speaking during the time allocated. Chabib Basirun (2007: the preface) said, "Quartet card game is one of the developments on Edutainment concept and it is hoped that the students can study about vocabularies and also expressions in English that are used in this game." 
In teaching speaking through quartet card game, it can make them to be interested and also will not feel bored in learning English. In playing quartet card game, students can communicate with each other, so they can practice their speaking skill in doing this activity with their own language. Students in elementary level still face so many difficulties since their words, sentences and expressions are still limited, and even they do not have enough time and many chances to communicate or speak in English. So by teaching speaking through quartet card game, it is hoped that the students can practice their speaking skill and communicate in English fluently. Quartet card game is able to reduce students' anxiety and to be used as a proper step of practice speaking, since they are expected to use their own words, sentences and expressions.

While it is difficult for the instructor to get individual to speak and participate, in a small group with their peers, they are more confident, less shy and willing to participate. In sum, quartet card game allows all members of the group to participate actively. They can also express and request their needs, information, etc.

\section{Research Question}

The research question is, then, formulated as follows; what kinds of speaking activities arise during playing quartet card game in the teaching of speaking skill at SMPN 275, East Jakarta?

\section{Objective of The Research}

The objective of the research is to find out what kinds of speaking activities arise during playing quartet card game in the teaching of speaking skill at SMPN 275, East Jakarta.

\section{Teaching Speaking}

The teaching of English covers the teaching of all four language skills. Reading, listening, writing, and speaking are taught integrated. It happens so since in a process of communication, the students use all of the skills. Learning foreign language is learning to communicate in the language orally and written.

Speaking skill is the main purpose in learning English. It is also supported by Powers (2010) statement that said:

Many language learners regard speaking as the measure of knowing a language. These learners define fluency as the ability to converse with others, much more than the ability to read, write, or comprehend oral language. They regard speaking as the most important skill they can acquire and they asses their progress in terms of their accomplishments in spoken communication.

The statement above is quite similar happened in a real life. It happens so, because there are so many people who come to an English course/institution want themselves to be fluent in speaking English. They think that speaking skill is the main thing that must be mastered in learning a language. They feel that the skill will help them in conversing with others and expressing their needs-request in their life.

In teaching speaking process, the teacher not only teaches about the skill but also give the explanation that speaking has three areas of knowledge. Powers (2010) also added that:

Language learners need to recognize that speaking involves three areas of knowledge: 
- Mechanics (pronunciation, grammar, and vocabulary): using the right words in the right order with the correct pronunciation.

- Functions (transaction and interaction): knowing when clarity of message is essential (transaction/information exchange) and when precise understanding is not required (interaction/relationship building)

- Social and cultural rules and norms (turn-taking, rate of speech, length of pauses between speakers, relative roles of participants): understanding how to take into account who is speaking to whom, in what circumstances, about what, and for what reason.

In teaching speaking, the teachers have to teach those knowledge to the students in order to prepare them in communicating to their environment. The students need to know all of them, because speaking is not just to produce sounds but also expressing ourselves formally and well structured.

In order to achieve it, all the students must take part actively during the learning-teaching process through the language activity given. To make it successful, the teacher should establish situations in encouraging students to practice their language. Teacher also must motivate them to speak English. Powers (2010) said:

There are some characteristics of a successful speaking activity:

a) Learners talk a lot. As much as possible of the period of time allotted to the activity is in fact occupied by learners talk.

b) Participation is even. Classroom discussion is not dominated by a minority of talkative participants, all get a chance to speak and contributions are fairly distributed.

c) Motivation is high. Learners are eager to speak, because they are interested in the topic and have something new to say about it, or because they want to contribute to achieving a task objective.

d) Language is an acceptable level. Learners express themselves in utterances that are relevant, easily comprehensible to each other, and of an acceptable level of language accuracy.

To reach those goals, a teacher has to use the right technique and strategy. He/she has to give the learners much time to practice and participate in learning the language skill. He/she also needs to use an interesting topic and simple words to make them understand and have a high motivation in learning the skill. Schmidt and Frota (1986) stated, "Effective instructors teach students speaking strategies; using minimal responses, recognizing scripts and using language to teach language".

a) Using Minimal Responses

One way to encourage learners who have lack confidence in their ability to participate in learning speaking process is to help them build up a stock of minimal responses that they can use in different types of exchanges. Minimal responses are predictable, often idiomatic phrases that 
conversation participants use to indicate understanding, agreement, doubt and other responses to what another speaker is saying. Having a stock of such responses enables a learner to focus on what the other participant is saying, without having to simultaneously plan a response.

b) Recognizing Scripts

Some communication situations are associated with a predictable set of spoken exchanges - a script. Greetings, apologies, compliments, invitations and other functions that are influenced by social and cultural norms often follow patterns or scripts. Instructors can help students develop speaking ability by making them aware of the scripts for different situations so that they can predict what they will hear and what they will need to say in response. Through interactive activities, instructors can give students practice in managing and varying the language that different scripts contain.

c) Using Language to Talk about Language

Language learners are often embarrassed or shy to say anything when they do not understand another speaker or when they realize that a conversation partner has not understood them. Instructors can help students overcome this reticence by assuring them that misunderstanding and the need for clarification can occur in any type of interaction, whatever the participants' language skill levels. By encouraging students to use clarification phrases in class when misunderstanding occurs and by responding positively when they do, instructors can create an authentic practice environment within the classroom itself. As they develop control of various clarification strategies, students will gain confidence in their ability to manage the various communication situations that they may encounter outside the classroom.

\begin{tabular}{lll}
\multicolumn{2}{c}{ Mastering speaking skill } \\
cannot be separated with
\end{tabular} vocabularies and grammar mastery. By mastering they will help the students in mastering the skill in language learning. It is hoped that by the end of the lesson they are able to:

a) Asking and answering about many things.

b) Having a short of conversation.

c) Giving explanation or description about thing, person, or place and the series of incident simply.

\section{The Definition and the Use of} Quartet Card Game in Teaching Speaking

Quartet card game is a set of cards that has many varieties of pictures, words, and categories. Chabib Basirun (2007) said, "Quartet card game consists of 40 (forty) cards with pictures and words on it and it can be played by two, three, or four players." Based on the statement, a teacher can use the game to practice students' language skill, especially speaking. This game provides so many pictures and words that can be used by the students to make sentences and then express it to their friends. 
The game also can be played by the large number of students. The teacher can ask the students to make four groups to play the game, and every personnel of the group can take part in the process of playing it.

This card is one of the variations or developments from the initial one. Formerly, Lengeling and Malarcher (2008) had made the variety of the card game into three categories.

Three categories of card game according to $M$. Martha Lengeling and Casey Malarcher:

a) Cards and words. This game is used to practice students' pronunciation.

b) Cards and sentences. This game is used to develop dialogs or for free conversation.

c) Cards and pictures. This game is used to describe the pictures' of something or someone stated on the card.

From the statements above, we can see some similarities on the characteristics among the cards. Both of the experts use words and pictures on the cards to help students in learning language. By using pictures and words, the experts hope that students will be able to memorize the words and describe the pictures. Because, in learning speaking they should have many vocabularies to make sentences.

The concept of this game is quite similar to the Indonesian one. The students will be given four pieces of card and they begin to look for the group of his/her cards by asking it to his/her friends.

There is a common perception that all learning should be serious and solemn in nature and that if one is having fun and there is hilarity and laughter, then it is not learning. This is a misconception. It is possible to learn a language as well as to enjoy oneself the same time. One best way of doing this is through games. It is supported by some experts' statement. W. R. Lee (2008) stated that, "most language games make learners use the language instead of thinking about learning the correct form." Lewis (2008) also added that, "games are fun and children like to play them. Through games children experiment, discover, and interact with their environment." Children enjoy their lessons when they feel free and happy in learning it. They will be dare to experiment, practice and interact using a language with their friends.

Games can be applied in teaching - learning English. It is said that games can be found to give practice in all skills (reading, writing, listening, and speaking) in all stages on teaching - learning sequences." It is supported by Aydan Ersoz' statement (2000) that, "games are highly motivating because they are amusing and interesting. They can be used to give practice in all language skills and be used to practice many types of communication." It happens so, because games are flexible techniques. We can practice all of language skills by using its materials.

Based on the statements above, it is clear that games can be applied in teaching all skills, one of them is speaking. Games have so many materials that can help students in learning all of language skills. It also helps the teacher to provide many activities that can be 
used by the students to practice their skills.

There are many reasons the teachers use games in teaching speaking. Games give students chance to use English orally, it means that the students can practice and develop their ability to speak English. Hansen (2008) said that, "games are highly motivating and entertaining, and they can give shy students more opportunity to express their opinions and feeling." Games provide fun and relax while remaining very much within the framework of language learning, it is expected for shy and slow learners can be active participants to show their ability and find their confidence in communicating in the foreign language. Aydan Ersoz (2008) said that: Supplementing regular lesson by a large of game activities motivates even the usually nonresponsive, shy passive on looker students, and the active participants, displaying their competence and newly found confidence in communicating in the foreign language.

Games in language teaching can motivate students to have more confidence in showing their competence in communicating in English. It happens so, because in playing game students do not have to feel scared when they make mistakes in expressing themselves.

Among many techniques of the games, quartet card game can be applied in the teaching of speaking at any level. The use of card and its variations has been widely used by the teachers in all over the world. It is supported by Lengeling and Malarcher's statement (2008) that: These cards become part of a teacher's permanent collection of resources since they are easily portable from classroom to classroom or country to country. In addition, these cards are often adaptable to other levels, so that one set of cards may provide two or three different activities.

It happens so because quartet card game has so many pictures, words, and category. It is related to the variations of card game that Lengeling and Malarcher used before. First, the students can use the pictures to maintain their vocabularies. It is done because children are interested in studying vocabularies when the teacher uses pictures as the explanation and they are easily to memorize it. Next, they can use the words to make a phrase, a sentence, or even an expression. The last, they can reach the objective of the game because in this game they are expected to look for the group of his/her cards by using request sentences.

That explanation is also supported by Chabib Basirun's statement (2007) that, "by playing quartet card game students are able to enrich their vocabularies and expressions." In this statement, he wants to emphasize that in this game, the students are not only expected to memorize vocabularies but also able to use many kinds of questions or expressions to express his/her goals, because mastering speaking skill should be started by mastering vocabularies and expressions largely. Speaking is a form of communication which is used to communicate with others to express their needs, request, information, and services.

The other objectives of quartet card game in teaching speaking have been explained by the 
writer before. The main objective in playing this game, it is expected that students can use some questions or request sentences to express his/her goals.

a) "Do you have ............?"

The question "do you have ........?" will come up in the game if the player is not sure whether his/her friend has the card that he/she wants or not. And, it is expected that the other players will answer "yes, I do", "yes, of course" or "no, I do not", "no, I am sorry I do not have it".

b) Can you give your ..........., please?

The question "can/could you give your ............., please?" or "can/could you give my ............. back, please? will be used by the player when he/she surely knows that the cards that he/she wants is in the other player. It is expected that the other players will answer "yes, I can/could", "yes, of course" or "no, I cannot/could not. You are wrong, I do not keep the card", "no, I am sorry I do not keep the card".

\section{RESEARCH METHOD}

In this research the writes use the qualitative descriptive research. By using this method, the writers may tell and explain the process of teaching speaking through quartet card game. The writers look for the data in two ways; library and field research. In the library research, the writers observe some theories from books. Whereas in the field research, they do observation, interview to the informants (students) and key informants (the teachers) and discussion. Based on the source of the data, the writers collect the data in two ways, library and field/action research. There are some techniques of collecting the data:

1. Recording the classroom dynamic during the teaching of speaking skill by using quartet card game. The electronic recording tool will be utilized during the teaching of speaking skill by using quartet card game in the classroom. By doing so, all data can obtained for the next step of analyzing them.

2. Doing an observation in the classroom. By doing an observation in the classroom, the writer can observe directly how is the way to teach speaking skill through quartet card game, strategy that used in teaching-learning process, difficulties in this activity, and also the situation in the classroom when this activity is done. The writer is also able to find out whether the students are interested in doing this activity or not.

3. Doing an interview to the informants (students) and key informants (the teachers). From the interview of the informants and key informants, the writer can know the responds of them on teaching speaking through quartet card game, the situation that the students want in doing this activity, and also the target of language that the teacher is expected after doing this activity. It is done to prepare the strategy on teaching speaking skill by using this game, know the influence of this game for the students to speak in English while or after playing this game.

4. Doing a discussion with the class teacher. By discussing with the class teacher, the writers are able to know how the role of the quartet card game technique is in teaching speaking toward the students' 
speaking ability. The writers are also able to find out whether the students are active enough in doing this activity.

5. Reading books related to the title of research. The writers read some books that related to the title in order to get knowledge and help him in making this reaserch easier and more accurately.

\section{FINDINGS AND DISCUSSION}

Teaching speaking to junior high school class is little bit difficult. The students have lack confidence and selfmotivation in learning the skill. Therefore, the teacher should have an appropriate technique that can make the students full of confidence in learning and practice the skill. Teachers also have to make the atmosphere of the classroom more interesting for the students to practice. Teacher's participation in the activity would help the students to overcome any inhibitions to learn and practice the language. They may have more desire and spirit to learn and practice the language since the atmosphere of the class is fun and relax.

The using of quartet card game in teaching speaking can make the process of teaching and learning speaking skill more enjoyable. The students are able to make and respond questions without feeling fear and shy. They also do not need to feel scared whether or not they make mistakes in speaking English.

The using of quartet card game in teaching speaking skill has its own advantages or strengths and disadvantages or weaknesses. Some of the advantages of using quartet card game are:

1. Quartet card game gives students a pleasure from regular activities in the classroom. It also creates a relaxed atmosphere in it.
2. Quartet card game can encourage students to communicate in English because the game is a combination between language practice with fun and excitement.

3. Quartet card game can practice the students' ability in forming many kinds of questions.

4. Quartet card game can be applied at various levels.

5. Quartet card game can be applied in many teaching lessons or topics.

Teaching speaking by using quartet card game could be an alternative way in teaching English at SMPN 275, Jakarta. The students are highly motivated in doing the activity and they like it very much. They speak more freely and do it happily. They also do not need to think whether their language is right or wrong. They just try to speak well to get the pairs of the cards from their friends. The card also brings fresh air in the learning situation and changes the atmosphere of the classroom becoming more relaxed.

But on the other side, the teacher should have so many varieties of card categories. It is done to make the teaching aid suitable with the lesson. The teacher also needs to pay attention while the students are playing the game to avoid them making mistakes in formulating questions.

Second, the students feel confused when they have new words to be made into sentences. Because of that reason, they tend to use the same questions while they are playing. In here, the teacher should vary their questions to avoid them using the same questions.

After the students have performed the tasks, the teacher helpthem to evaluate how far they have the tasks. From the teacher's formative test, the students will find out how well they have done the tasks. The teacher evaluates the students' answers together 
with their friends. It is done to show how far they comprehend the way to make and respond request sentences.

\section{CONCLUSION}

Speaking skill is one of the skills that has to be mastered by the students in learning English. This skill is taught to the students in order to make them be more able to communicate in English fluently. However, many factors hamper the students to speak in English. These problems sometimes come because of the lack of teacher's techniques in teaching the language skill. The teacher may not fulfill the students' need or he/she does not have other teaching techniques to be used in teaching the language skill. As the result, the students' motivation in learning English tends to fade out.

Quartet card game is a technique that can be used in teaching speaking. Quartet card game is quite simple; the students just have to look for the pairs of cards by asking it to their friends. Through this game, the students can practice their ability in formulating questions and they have a freedom in expressing their ideas during the game. In addition, by using this game the students are highly motivated to speak in English. It also brings the students into the enjoyable situation while they are learning the language skill, and it also helps the teacher in learning and teaching process.

Teaching speaking by using quartet card game is divided into five stages:

1. Teacher socializes quartet card game.

2. Teacher asks the students to play it individually or in a group.

3. Teacher distributes cards.

4. Teacher directs the students to practice the game.
5. Teacher gives tasks to the students. In teaching speaking by using quartet card game, there are some useful hints that the researchers tries to suggest. It comes from the condition that the findings of the research might not represent the general condition of any card games playing. Therefore, the next similar research should be done in the higher level of high school students, or the same level of students in the other junior high schools in the other cities. These should focus on expecting various part of speech used or expressed by the students when playing the game.

\section{REFERENCES}

Basirun, C. (2007). The Preface on Quartet Card Game. Jakarta: PT Primadaya_tc,

Ersoz, A. (2000). Six Games for the EFL/ESL Classroom. Retrieved from

http://www.teflgames.com/why. html.

Hansen. (2008). The Use of Games for Vocabulary Presentation and Revision. Retrieved from http://www.teflgames.com/why. html.

Lee, W. R. (2008). The Use of Games for Vocabulary Presentation and Revision. Retrieved from http://www.teflgames.com/why. html.

Lengeling, M. M. and Malarcher, C. (2008). Index Cards: A Natural Resource for Teachers. http://exchanges.state.gov/forum /vols/vol35/no4/p42.htm.

Lewis. (2008). Using Games in an EFL Class for Children. Retrieved from 
http://www.teflgames.com/why. html.

Powers, D. E. (2010). The Case for a Comprehensive, Four-Skills Assessment of EnglishLanguage Proficiency. (R\&D Connections No. 14). Princeton, NJ: Educational Testing Service.
Schmidt, R. W., and S. N. (2008). Frota. Developing Basic Conversational Ability in a Second Language. Retrieved from http://www.nclrc.org/essentials/s peaking/spindex.htm. 